\title{
Innovation of Exhibition Industry Development Path in Shaanxi Free Trade Zone
}

\author{
Peng Zhang \\ Xi'an International University, Shaanxi Institute for Free Trade Zone Research, Xi'an City, Shaanxi Province, \\ 710077, China
}

Keywords: Shaanxi Free Trade Zone; Exhibition industry; Development path; Innovation

\begin{abstract}
Shaanxi Free Trade Experiment Area is the third batch of free trade test area approved by the Party Central Committee and the State Council in August 31, 2016. It is the only free trade test area in Northwest China. The construction of the free trade zone in Shaanxi has led to a new round of development in the exhibition industry. Under the new economic situation, the exhibition industry has shared the exhibition infrastructure and advantages brought by the free trade zone, and has got better development opportunities. Based on the learning and practical experience of the author, this paper firstly interpreted the traditional development model of Shaanxi exhibition industry, and then constructed a new model of exhibition industry development in the context of free trade zone, and finally put forward relevant policies, safeguards and suggestions.
\end{abstract}

\section{Introduction}

Shaanxi (China) Free Trade Test Area covers a total area of 119.95 square kilometers, covering three areas. The Central Free Trade Test Area focuses on the development of strategic emerging industries and high-tech industries, emphasizing on the development of high-end manufacturing, aviation, logistics, trade, finance and other industries. Further, it will promote service trade and the construction of the system, and expand the depth and breadth of human and cultural exchanges, such as science and technology, education, culture, tourism, health care, etc. Xi'an International Port Area focuses on the development of international trade, modern logistics, financial services, tourism, convention and exhibition, e-commerce and other industries; Yangling Demonstration Area is characterized by agricultural science and technology innovation, demonstration and promotion. It will create "The Belt and Road" modern agriculture international cooperation center through comprehensively expanding international cooperation and exchanges in agriculture. Therefore, the local conference and exhibition industry will also face new situations and new changes after the establishment of free trade zones.

\section{Traditional Development Model of Exhibition Industry in Shaanxi Province}

Analysis on exhibition hall operation mode. In China, there are four forms of successful pavilion management: First, it was built by the government and was managed by commissioned enterprises. secondly, it was funded by the government and also was managed by the government; thirdly, it was a joint venture by singly managed through enterprise operation; fourth, it also was a joint venture managed by grouped diversification. The exhibition industry of Shaanxi faces the fierce competition situation of domestic exhibition venues and draws on successful experiences at home and abroad. However, from the exhibition situation, the operation is not very ideal: The operation cost of exhibition hall is high with no entrance of international brand exhibition; in addition, the pavilion's revenues are low with its small activities and meetings, making the envisioned "Germany plus Hongkong" model unsuccessful.

Analysis on the meeting operation model. The favorable geographical conditions and economic status of Shaanxi province have been continuously promoted, which has created conditions for the important meetings at home and abroad. In the past, meetings held by the government and some non-governmental organizations were mostly made by themselves and rarely 
entrusted to professional meeting companies. But now, the way in which conferences are operating is changing dramatically. With the continuous improvement of the degree of specialization of breakthrough meeting and conference technology, government and non-governmental organizations are increasingly favored and rely on the meeting agency, making the government gradually emerge from the arrangements for the daily meeting. This greatly improves the efficiency of government. At the same time, all kinds of professional conference organizers have come into being, and the content of services has become more and more diverse. In addition to some basic services, some professional conference organizations offer services that meet the specific needs of customers.

Analysis on the festivals and events operation. Over the years, the festival and events in Shaanxi have shown a spectacular development, and nurtured some world-famous festivals and festivals with many local characteristics. But as a whole, the organizers and contractors are basically all levels of government and related functional departments. Companies and enterprises and other social forces participating in hosting and hosting festivals are rare.

\section{New Model of Exhibition Industry Development under the Background of Shaanxi Free Trade Zone}

Construction of venue management model in Shaanxi exhibition industry. From the Shaanxi exhibition industry operation process, we can combine their own situation, learn from each other, and selectively combine the characteristics of various operational modes to optimize their own business model. We should learn German model and strengthen independent exhibition efforts with brave innovation; moreover, we should learn the Hongkong model to attract conference activities and separate property management from venue management; we should draw on the experience of the United States. To be specifically, the venue operators should outsource the exhibition services to the service providers and collect a commission or purchase the service products of the service providers. Further, we can sell it to the organizers and earn the middle price; We should learn from the mode of cooperation between China and foreign countries, and form a holding group with famous foreign exhibition companies to cultivate exhibitions together. In the process of learning and reference, we must continue to improve and form a unique and comprehensive mode.

Construction of the meeting operation model. In terms of the meeting operation, the past meetings were dominated (or led) by the government. In the future, more and more related aspects, including social groups, enterprises, travel agencies, hotels and other conference business chains will enter and form a new conference operation mode. Shaanxi has perfect infrastructure and complete service facilities, and has the unique advantages of developing conference business. To this end, the Shaanxi provincial conference operation model can be considered from the following aspects of breakthroughs: Firstly, they will build a government oriented conference operation model. Development must vigorously accelerate the government leading high-end meeting with efforts on strengthening international cooperation, and actively cultivate own brand conference, such as international meetings, conferences, business meetings and public relations marketing, enterprise incentive meetings and activities and training sessions. Secondly, they will create a professional organization led conference operations model and actively hold and undertake various professional types of meetings, so that to create their own conference brand and form a unique leading mode of operation. Thirdly, they will build conference management and consulting business model. They provide high level conference management, consultation, and conference operation services to internationally renowned forums and high-end meetings. Moreover, they will focus on creating or introducing conferences with great potential and leading functions for the economic development, such as Summit of East Asian Economic Exchange Promotion Agency and China UK Urban Creative Industry Forum, etc.

The construction of the festivals and events operation model. Festivals and events activities currently have a certain public nature. Thus, completely market-oriented operation model is not realistic and may not work for most of the festivals and events activities. As for the model of "government guidance, enterprise undertaking and market operation", it is in line with the national 
conditions and the specific realities of most cities. In this mode, we put the city management mechanism in the "government-led, market-operated and industry-held festival" platform following the basic requirements of the market mechanism in the allocation of resources to the festival. Moreover, we will take the whole festival as a systematic cultural, festival and investment promotion initiative to achieve the "win-win situation" in social and economic benefits. With the constant maturity and growth of Shaanxi convention and exhibition industry, we will gradually develop better festival and event projects to market in the mature market conditions.

\section{Policy Guarantee Measures and Suggestions for the New Model of Exhibition Industry Development in Shaanxi}

Formulate long-term industrial policies for urban conference and exhibition industry. The industrial policy of a city is an important means to control the city's economic development, and is an important factor in determining the direction, scale and speed of the city's industrial development. As for the exhibition industry, the first should be said is the regional support policy of exhibition industry. According to the current situation of exhibition industry, the regional distribution of exhibition resources and the necessary conditions for the development of exhibition industry, we can only select and focus on the development of the exhibition industry and formulate reasonable regional support policies. We should make a reasonable division for the key development areas and non key development areas of the exhibition industry. Further, we should provide tax relief, land use concessions, financial subsidies and other policies for exhibitions in line with the industrial layout policy. The second is the industry support policy of the exhibition industry. According to the emphasis of industrial development and the layout of different industries in different regions, we should select related industries to give policy support; the third is the enterprise support policy. In order to realize the goal of becoming bigger and stronger, Shaanxi exhibition industry must protect and support the famous brand exhibition, speeding up the pace of the similar exhibition, and promote the scale and collectivization of the exhibition industry.

Make strenuous efforts to cultivate a variety of exhibition market operators. In order to develop the exhibition industry, it is necessary for all parties to actively promote the establishment and transplantation of exhibition brands; moreover, we should cultivate, shape and retain a number of the main body of exhibition company with operational norms and large-scale exhibition industry. According to the exhibition industry development experience at home and abroad combined with the actual situation of Shaanxi Province, we also should make full use of favorable factors, play the enthusiasm of each industry association exhibition and vigorously introduce the international exhibition of large multinational enterprises. Furthermore, we should speed up the reform of the existing state-owned exhibition enterprises, actively support and strengthen the private exhibition companies, and strengthen the cultivation and support of exhibition enterprises with diversified ownership economies, so as to strengthen the exhibition industry in Shaanxi province.

Efforts to develop a variety of specialized exhibition supporting services enterprises. The exhibition industry involves many trades and many types of services. In addition to the exhibition company as the leader of the exhibition, it also needs exhibition design, exhibition booth building, exhibition transportation, exhibition equipment leasing, exhibition advertising, catering, accommodation and other ancillary services. Such services form professional service groups of enterprises based on the market demand, and implement professional division of labor. In a fair and orderly market competition, such services provide high-quality professional services to the exhibition, and form a highly efficient and high-quality exhibition service system.

Standard to evaluate the qualification and reputation of exhibition enterprises. We should carry out the evaluation system of the legal personality of exhibition industry. Like corporate reputation rating and hotel star rating, we should evaluate the objective and true corporate bodies of different exhibition enterprises. Reputation rating of exhibition brand and legal person qualification will greatly reduce the transaction cost of exhibition industry. This will play a positive role in safeguarding the market order of the exhibition industry, promoting the survival of the fittest and protecting the interests of the participants. 
Establishment of exhibition economy information center. The establishment of the exhibition economy information center ensures the credibility of the information center through the system restriction; it also sets up the authority of the information center and reduces the information cost of the industry operation. To this end, on the one hand, the information center will announce important information on the development of the industry; on the other hand, it also will announce the exhibition enterprises and practitioners qualifications. It is convenient for exhibitors to inquire about the qualification and reputation of the organizers of the exhibition and to make correct decisions through online inquiry.

Establish a statistical system for exhibition industry. Statistical data is an important reference for the formulation of economic policies. However, the exhibition industry has attracted more and more attention in recent years. Most cities have not included the exhibition data into the national economic system, and most of the data are scattered. Therefore, the quick establishment of the exhibition industry statistical system and the real development of the exhibition industry are the basic work for formulating the long-term development policy of the exhibition industry.

\section{Summary}

Shaanxi free trade experiment area brings good opportunities for exhibition industry. Therefore, the organizers of the exhibition should innovate the operation mode of exhibition venues, conference operation mode and festival and events operation mode, so that to promote their own development. Therefore, only by seizing the opportunity, enhancing the overall economic strength of the city, improving the comprehensive level of the whole exhibition industry chain and upgrading the software and hardware, can the Shaanxi exhibition industry keep a good growth space.

\section{References}

[1] Fang Luping. SWOT Analysis of Fuzhou Exhibition Industry under the Background of Fujian Free Trade Zone[J]. Journal of Fujian Institute of Education, 2016, (01): 49-53.

[2] Xu Xiaowei. Analysis of Tourism Development Opportunities under the Background of Fujian Free Trade Zone[J]. Journal of Yueyang Vocational Technical College, 2015, (05): 117-120.

[3] Hu Sumin. Two New Policies of Shanghai FTA on Helping the Exhibition Industry Development,[N]. China Trade Daily, 2015-07-21 (007).

[4] Shi Ju. A Comparison of the Policies of Shanghai Free Trade Zone and the World's Major Free Trade Zones[J]. China Foreign Trade, 2015, (06): 44-45.

[5] Lv Zhaohua. Research on the Development of Exhibition Logistics in China ASEAN Expo[D]. Guangxi University, 2015.

[6] Liu Haiying. Development Trend and Path of Exhibition Industry in 2015[N]. China Trade Daily, 2015-01-13 (005) 